\title{
Three-Terminal Amorphous Silicon Solar Cells
}

\author{
Cheng-Hung Tai, ${ }^{1}$ Chu-Hsuan Lin, ${ }^{1}$ Chih-Ming Wang, ${ }^{1}$ and Chun-Chieh Lin ${ }^{2}$ \\ ${ }^{1}$ Institute of Opto-Electronic Engineering, National Dong Hwa University, Shoufeng, Hualien 97401, Taiwan \\ ${ }^{2}$ Department of Electrical Engineering, National Dong Hwa University, Shoufeng, Hualien 97401, Taiwan
}

Correspondence should be addressed to Chu-Hsuan Lin, chlin0109@mail.ndhu.edu.tw

Received 15 June 2011; Accepted 5 September 2011

Academic Editor: Vincenzo Augugliaro

Copyright ( 92011 Cheng-Hung Tai et al. This is an open access article distributed under the Creative Commons Attribution License, which permits unrestricted use, distribution, and reproduction in any medium, provided the original work is properly cited.

\begin{abstract}
Many defects exist within amorphous silicon since it is not crystalline. This provides recombination centers, thus reducing the efficiency of a typical a-Si solar cell. A new structure is presented in this paper: a three-terminal a-Si solar cell. The new backto-back p-i-n/n-i-p structure increased the average electric field in a solar cell. A typical a-Si p-i-n solar cell was also simulated for comparison using the same thickness and material parameters. The $0.28 \mu \mathrm{m}$-thick three-terminal a-Si solar cell achieved an efficiency of $11.4 \%$, while the efficiency of a typical a-Si p-i-n solar cell was $9.0 \%$. Furthermore, an efficiency of $11.7 \%$ was achieved by thickness optimization of the three-terminal solar cell.
\end{abstract}

\section{Introduction}

Amorphous silicon (a-Si) for photovoltaic applications can be deposited using the techniques of plasma-enhanced chemical vapor deposition (PECVD) [1-3], catalytic CVD (Cat-CVD) $[4,5]$, photo-CVD [6,7], sputtering [8], and so forth. Since it is usually deposited at a low temperature, lowcost or flexible materials like glass, plastic, or stainless steel can be adopted as the substrate. Amorphous Si also has the advantages of an abundant supply on the earth and a highabsorption coefficient at visible wavelengths $[9,10]$. These advantages make it promising for applications in thin-film photovoltaics. Amorphous Si can be applied to many types of solar cells, such as single-junction [11, 12], multijunction $[13,14]$, and HIT [15] (heterojunction with intrinsic thin layer) solar cells. In 2000, the stable efficiency of a singlejunction a-Si solar cell (area of $1 \mathrm{~cm}^{2}$ ) was 9.0\% [16]. In 2009. a single-junction a-Si solar cell has achieved an efficiency of $10.1 \%$ [17]. Multijunction solar cells were usually able to achieve higher efficiencies. For example, the stable efficiency of a triple-junction solar cell (a-Si/a-Si/a-SiGe tandem solar cell) was $12.1 \%$ [18], and the efficiencies of micromorph Si solar cells (a-Si/ $\mu \mathrm{c}-\mathrm{Si}$ tandem solar cells) were larger than $11 \%$ [19-21]. Multijunction solar cells are composed of two or more subcells. The working mechanism of multijunction solar cells is by way of tunnel-recombination junctions, and the final efficiency is limited by the smallest photogenerated current among all subcells [22]. This is because each subcell of a multijunction solar cell must pass through the same current. Therefore, the defects inside the a-Si may reduce the efficiencies of solar cells whether for a single-junction cell or a multijunction cell. The efficiencies are reduced due to the recombination of photogenerated carriers via defects $[23,24]$. In addition, carrier mobility in a-Si is quite low. Hence, the efficiencies of typical a-Si-based solar cells are limited.

We have designed and simulated a new structure of a three-terminal a-Si $\mathrm{p}-\mathrm{i}-\mathrm{n} / \mathrm{n}-\mathrm{i}-\mathrm{p}$ solar cell. The new structure enhances the electric field in a-Si solar cells and reduces the recombination rate of photogenerated carriers in order to increase the efficiency. The three-terminal device structure also avoids the effect of current mismatch between subcells [25]. In this paper, we compare the two-terminal a-Si p-i$\mathrm{n}$ solar cell (control cell) and the new three-terminal a-Si $\mathrm{p}-\mathrm{i}-\mathrm{n} / \mathrm{n}-\mathrm{i}-\mathrm{p}$ solar cell with the same thickness and material parameters.

\section{Device Structure}

Figure 1 shows the device structures and doping concentrations of the single-junction a-Si p-i-n solar cell (labeled as control) and the three-terminal a-Si p-i-n/n-i-p solar cell 


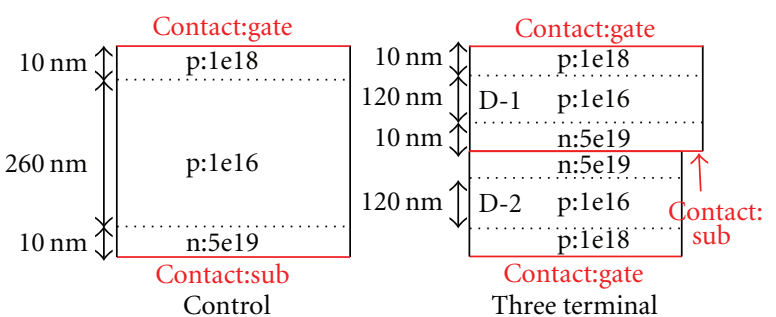

FIGURE 1: The structures of the two-terminal a-Si solar cell (labeled as control) and the three-terminal a-Si solar cell (labeled as three terminal). The thicknesses of the control cell and the three-terminal cell were both $0.28 \mu \mathrm{m}$.

(labeled as three terminal). The simulation was carried out with the commercial simulation tool, ISE TCAD. The device structure and performance of the control cell were based on those in [16]. Sunlight irradiated the cells from the top of the device. In our simulation, all of the p-layers and n-layers had a thickness of $0.01 \mu \mathrm{m}$, and both the control cell and the three-terminal cell were $0.28 \mu \mathrm{m}$.

In order to contact "contact:sub" in the three-terminal solar cell, we should set the width of the subcell D-2 (see the definition in Figure 1) to be smaller than the width of the subcell D-1. Then, "contact:sub" could connect to the outer circuit. For a large area solar cell, the ratio of the contact region of "contact:sub" to the total area would be very small, and the influence due to the width decrease of the subcell D-2 could be neglected. On the other hand, the top "contact:gate" and bottom "contact:gate" of the three-terminal cell were joined and acted as the other terminal to the outer circuit.

For the control cell, most of the depletion region was in the intrinsic layer (i-layer). The photogenerated carriers were separated by an electric field of the depletion region and the electrons drifted to the "contact:sub," while the holes drifted to the "contact:gate". For the three-terminal cell, there are i-layers both in subcells D-1 and D-2. As with the control cell, most of the depletion region was in the i-layers. It is worth noting that the directions of the electric field in D-1 and D-2 are reversed. All of the photogenerated electrons in the three-terminal cell will drift to "contact:sub." The photogenerated holes in D-1 will drift to the top "contact:gate," and the photogenerated holes in D2 will drift to the bottom "contact:gate."

\section{Results and Discussion}

The key role in improving the efficiency of the three-terminal cell is the electric field in the i-layers. For a two-terminal cell, the built-in potential is distributed across the $0.28 \mu \mathrm{m}$ thick p-i-n structure. For a three-terminal cell, the same magnitude of the built-in potential is distributed across both the top p-i-n and bottom n-i-p structures. Hence, the average electric field of the three-terminal cell is larger than the control cell.

Figure 2 gives the I-V characteristics of the control cell and the three-terminal cell. In [16], the stable efficiency of a single-junction thin a-Si: $\mathrm{H} \mathrm{p}$-i-n solar cell was $9.0 \%$, the

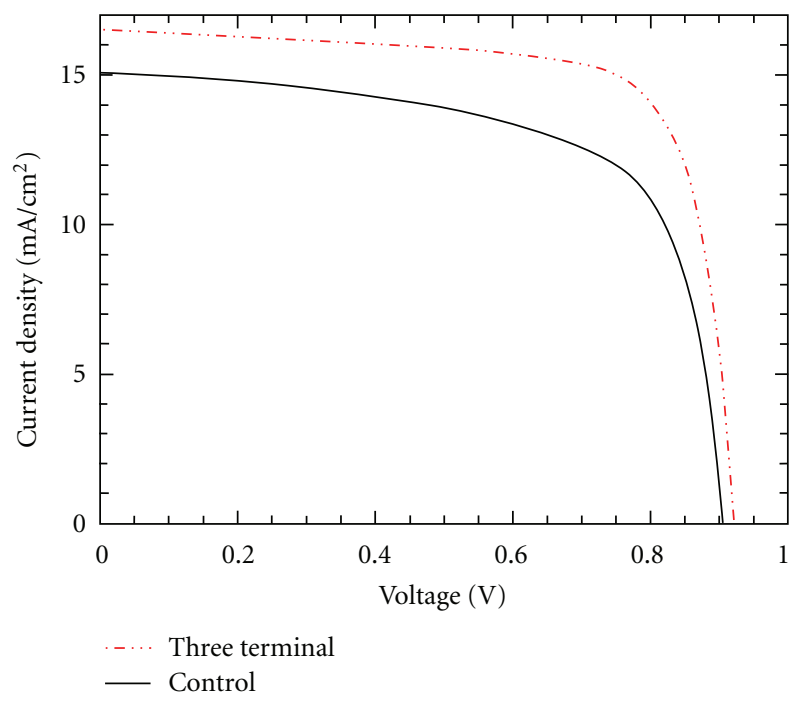

Figure 2: The I-V characteristics of the control cell and the threeterminal cell. The efficiency of the control cell was 9.0\%, and the efficiency of three-terminal cell was $11.4 \%$.

short-circuit current density $\left(J_{\mathrm{SC}}\right)$ was $15.8 \mathrm{~mA} / \mathrm{cm}^{2}$, and the open-circuit voltage $\left(V_{\mathrm{OC}}\right)$ was $0.87 \mathrm{~V}$. For the control cell in our simulation, the efficiency was $9.0 \%$, the $J_{\mathrm{SC}}$ was 15.2 $\mathrm{mA} / \mathrm{cm}^{2}$, and the $V_{\mathrm{OC}}$ was $0.91 \mathrm{~V}$. It was proved that our simulation results were close to the practical conditions. For the three-terminal cell, the efficiency was $11.4 \%$, the $J_{\mathrm{SC}}$ was $16.5 \mathrm{~mA} / \mathrm{cm}^{2}$, and the $V_{\mathrm{OC}}$ was $0.92 \mathrm{~V}$. The efficiency of the three-terminal a-Si solar cell was remarkably increased. A larger average electric field in the three-terminal cell could decrease the recombination of photogenerated carriers, and so that the efficiency was enhanced.

Figure 3 shows the generation rate $\left(1 /\left(\mathrm{cm}^{3} \cdot \mathrm{s}\right)\right)$ and recombination rate $\left(1 /\left(\mathrm{cm}^{3} \cdot \mathrm{s}\right)\right)$ of the control cell and the three-terminal cell. It could be observed that the control cell and the three-terminal cell had the same generation rate, but the three-terminal cell had a lower recombination rate than the control cell. The integral of the recombination rate over the depth was the amount of total bulk recombination. The integrals were $8.32 \times 10^{12}\left(1 /\left(\mathrm{cm}^{2} \cdot \mathrm{s}\right)\right)$ and $23.27 \times 10^{12}$ $\left(1 /\left(\mathrm{cm}^{2} \cdot \mathrm{s}\right)\right)$ for the three-terminal cell and the control cell, respectively. The three-terminal cell had a smaller total bulk recombination, and so the efficiency of the three-terminal solar cell was higher than the control solar cell.

Figure 4 shows the band-edge diagram of the control cell and the three-terminal cell when sunlight irradiated from the left side of the band-edge diagram. With this band-edge diagram, it could be understood that, in the control cell, the photogenerated electrons would drift to the n-layer and the photogenerated holes would drift to the p-layer. In the control cell, "contact:sub" acted as the negative electrode of the solar cell, and "contact:gate" acted as the positive electrode. In the three-terminal cell, all of the photogenerated electrons would drift to the n-layer and connect to the outer circuit via "contact:sub" between the two n-layers. The photogenerated holes in the subcell D1 would drift to the top p-layer and connect to the outer 


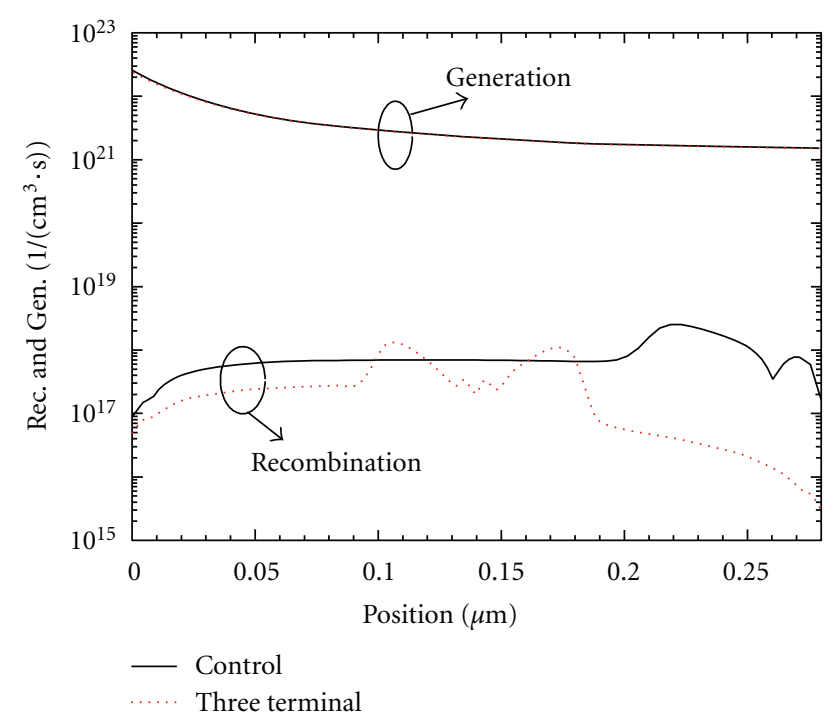

FIgURE 3: The generation and recombination rates of the control cell and the three-terminal cell. The control cell and the threeterminal cell have the same generation rate.

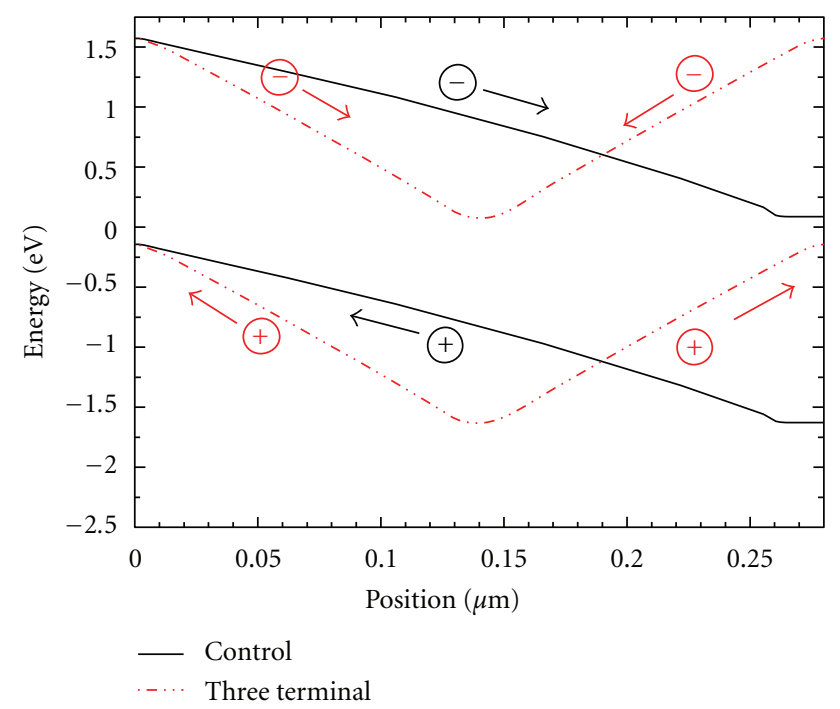

FIgURE 4: The band-edge diagram of the control cell and the threeterminal cell. The arrows show the drift directions of photogenerated carriers.

circuit via the top "contact:gate" on the top surface. The photogenerated holes in the subcell D-2 would drift to the bottom p-layer and connect to the outer circuit via the bottom "contact:gate." Then, the top "contact:gate" and the bottom "contact:gate" were joined by metals. The directions of the photogenerated carrier flows of the three-terminal cell and the outer circuit were shown in Figure 5. Similar to the control cell, "contact:sub" in the three-terminal cell acted as the negative electrode, and two "contact:gates" acted as the positive electrode.

The thicknesses of the subcell D-1 and the subcell D-2 of the previous three-terminal cell were both $0.14 \mu \mathrm{m}$. We

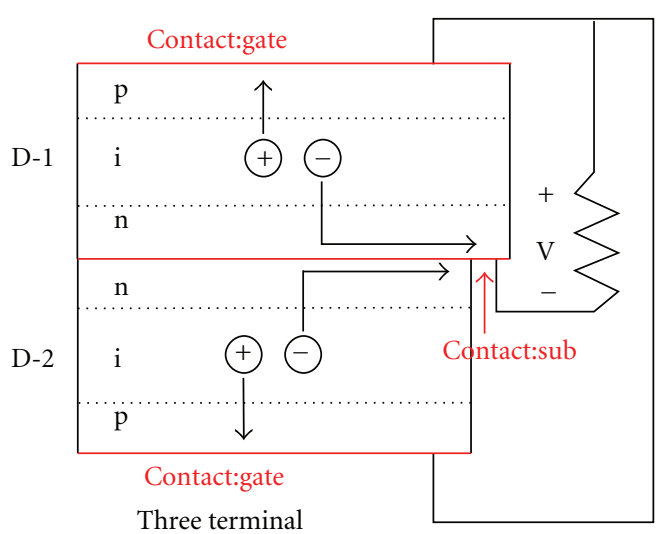

Figure 5: A simple diagram of the carrier flows and the outer circuit. The top "contact:gate" and the bottom "contact:gate" are assumed to be joined and act as the positive electrode of the threeterminal cell. The "contact:sub" acts as the negative electrode of the three terminal cell.

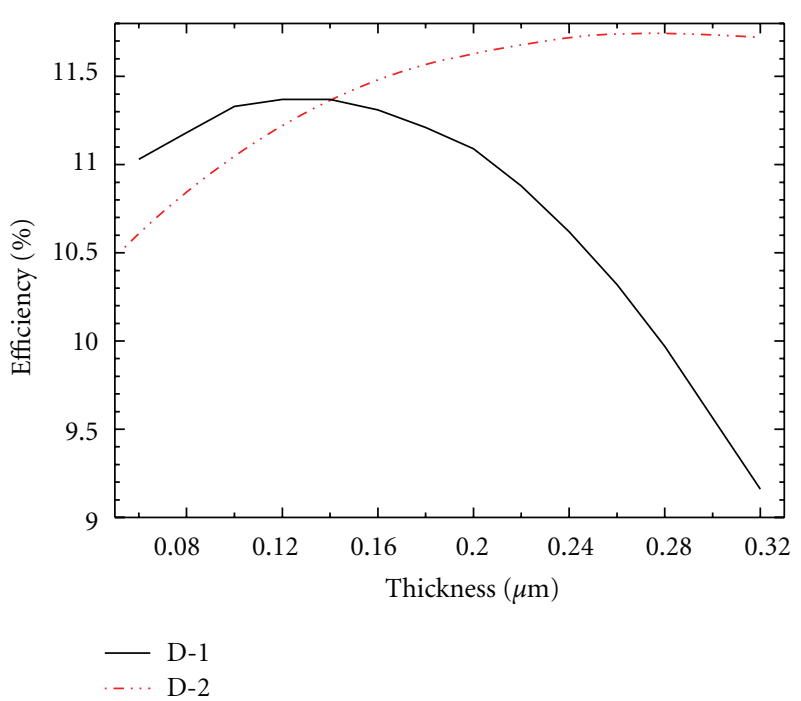

FIGURE 6: The efficiency as a function of the thickness of the subcell $\mathrm{D}-1$ or the subcell D-2. The highest efficiency occurs when the thickness of the subcell D-1 is $0.14 \mu \mathrm{m}$.

optimized the three-terminal cell by adjusting the thickness of the subcell D-1 and the subcell D-2 (Figure 6). First, we kept the thickness of the subcell D-2 at $0.14 \mu \mathrm{m}$ and adjusted the thickness of the subcell D-1 from $0.06 \mu \mathrm{m}$ to $0.32 \mu \mathrm{m}$. We obtained the highest efficiency when the thickness of the subcell D-1 was $0.14 \mu \mathrm{m}$. Therefore, the thickness of the subcell D-1 was kept at $0.14 \mu \mathrm{m}$, and the thickness of the subcell D-2 was adjusted from $0.06 \mu \mathrm{m}$ to $0.32 \mu \mathrm{m}$. The thicker the subcell D-2, the higher the efficiency. The efficiency almost saturated as the thickness became greater than $0.24 \mu \mathrm{m}$. From the simulation results, we obtain the following conclusions: (I) as the thickness of the subcell D2 is fixed and the thickness of subcell D-1 is smaller than $0.14 \mu \mathrm{m}$, a thinner subcell $\mathrm{D}-1$ will produce a lower $J_{\mathrm{SC}}$ in the three-terminal cell as a result of insufficient absorption, thus leading to a lower efficiency; (II) the thicker the subcell 
$\mathrm{D}$-1, the greater the overall $J_{\mathrm{SC}}$, but the lower the overall $V_{\text {OC. }}$ Therefore, the efficiency decreases if this subcell is too thick (thicker than $0.14 \mu \mathrm{m}$ ). The reason for decreasing in the overall $V_{\mathrm{OC}}$ as the thickness increases is discussed as follows. When the subcell D-1 is too thick, most of sunlight is absorbed by the subcell $\mathrm{D}-1$, which leads to the decrease in absorption in the subcell $\mathrm{D}-2$. This reduces the photogenerated current in the subcell D-2, and therefore the subcell D-2 has a lower $V_{\mathrm{OC}}$ than the subcell D-1. For a threeterminal cell, subcells D-1 and D-2 are connected in parallel to the circuit. Consequently, the reduced $V_{\mathrm{OC}}$ of the subcell D-2 will decrease the overall $V_{\mathrm{OC}}$ of the three-terminal cell; (III) on the other hand, as the thickness of the subcell D-1 is fixed, a thicker subcell D-2 absorbs more incident light, leading to the higher $J_{\mathrm{SC}}$ and efficiency.

\section{Summary}

We designed and simulated a new three-terminal a-Si solar cell. This structure improved the efficiency limitation that existed as a result of defects of a-Si solar cells. The efficiency of a $0.28 \mu \mathrm{m}$-thick thin-film three-terminal a-Si solar cell achieved $11.4 \%$. The efficiency of the three-terminal a-Si solar cell could reach $\sim 11.7 \%$ with the optimized thickness.

\section{Acknowledgments}

The authors are grateful to the National Center for HighPerformance Computing for computer time and facilities (ISE TCAD). This work is supported by the National Science Council of Taiwan. under Contract no. 97-2218-E-259-006 and no. 98-2221-E-259-002-MY3.

\section{References}

[1] A. Matsuda, "Thin-film silicon—growth process and solar cell application," Japanese Journal of Applied Physics, vol. 43, no. 12, pp. 7909-7920, 2004.

[2] P. Leempoel, P. Descamps, T. Kervyn de Meerendré et al., "Distributed electron cyclotron resonance plasma: a technology for large area deposition of device-quality a-Si:H at very high rate," Thin Solid Films, vol. 516, no. 20, pp. 6853-6857, 2008.

[3] M. Brinza, J. K. Rath, and R. E. I. Schropp, "Thin film silicon n-i-p solar cells deposited by VHF PECVD at $100 \circ \mathrm{C}$ substrate temperature," Solar Energy Materials and Solar Cells, vol. 93, no. 6-7, pp. 680-683, 2009.

[4] K. Chikusa, K. Takemoto, T. Itoh, N. Yoshida, and S. Nonomura, "Preparation of B-doped a-Si1-xCx:H films and heterojunction p-i-n solar cells by the Cat-CVD method," Thin Solid Films, vol. 430, no. 1-2, pp. 245-248, 2003.

[5] K. Sugita, K. Koyama, K. Ohdaira, and H. Matsumura, "Relationship between textured structure of substrates and defect density of catalytic chemical vapor deposition amorphous silicon films," Japanese Journal of Applied Physics, vol. 46, no. 5, pp. 2852-2857, 2007.

[6] S. Hiza, A. Yamada, and M. Konagai, "Low-temperature deposition of hydrogenated microcrystalline silicon thin films by photochemical vapor deposition technique and their application to thin film solar cells," Japanese Journal of Applied Physics, vol. 46, no. 4, pp. 1427-1431, 2007.
[7] J. Kwak, S. W. Kwon, and K. S. Lim, "Fabrication of a n-p-p tunnel junction for a protocrystalline silicon multilayer/amorphous silicon tandem solar cell," Journal of NonCrystalline Solids, vol. 352, no. 9-20, pp. 1847-1850, 2006.

[8] T. D. Moustakas, "Photovoltaic properties of amorphous silicon produced by reactive sputtering," Solar Energy Materials, vol. 13, no. 5, pp. 373-384, 1986.

[9] B. Rech and H. Wagner, "Potential of amorphous silicon for solar cells," Applied Physics A, vol. 69, no. 2, pp. 155-167, 1999.

[10] J. Yang, A. Banerjee, and S. Guha, "Amorphous silicon based photovoltaics - from earth to the 'final frontier," Solar Energy Materials and Solar Cells, vol. 78, no. 1-4, pp. 597-612, 2003.

[11] T. Nishimoto, M. Takai, H. Miyahara, M. Kondo, and A. Matsuda, "Amorphous silicon solar cells deposited at high growth rate," Journal of Non-Crystalline Solids, vol. 299-302, no. 2, pp. 1116-1122, 2002.

[12] A. Čampa, O. Isabella, R. van Erven et al., "Optimal design of periodic surface texture for thin-film a-Si:H solar cells," Progress in Photovoltaics: Research and Applications, vol. 18, no. 3, pp. 160-167, 2010.

[13] H. Keppner, J. Meier, P. Torres, D. Fischer, and A. Shah, "Microcrystalline silicon and micromorph tandem solar cells," Applied Physics A, vol. 69, no. 2, pp. 169-177, 1999.

[14] E. Maruyama, S. Okamoto, A. Terakawa, W. Shinohara, M. Tanaka, and S. Kiyama, "Toward stabilized 10\% efficiency of large-area $(>5000 \mathrm{~cm} 2)$ a-Si/a-SiGe tandem solar cells using high-rate deposition," Solar Energy Materials and Solar Cells, vol. 74, no. 1-4, pp. 339-349, 2002.

[15] M. Taguchi, E. Maruyama, and M. Tanaka, "Temperature dependence of amorphous/crystalline silicon heterojunction solar cells," Japanese Journal of Applied Physics, vol. 47, no. 2, pp. 814-818, 2008.

[16] J. Meier, U. Kroll, S. Dubail et al., "Efficiency enhancement of amorphous silicon $\mathrm{p}-\mathrm{i}-\mathrm{n}$ solar cells by LP-CVD ZnO," in Proceedings of the 28th IEEE Photovoltaic Specialists Conference, p. 746, September 2000.

[17] S. Benagli, D. Borrello, E. Vallat-Sauvain et al., "Highefficiency amorphous silicon devices on LPCVD-ZnO TCO prepared in industrial KAI TM-M R \& D reactor," in Proceedings of the 24th European Photovoltaic Solar Energy Conference, p. 2293, 2009.

[18] J. Yang, A. Banerjee, and S. Guha, "Triple-junction amorphous silicon alloy solar cell with $14.6 \%$ initial and $13.0 \%$ stable conversion efficiencies," Applied Physics Letters, vol. 70, no. 22, pp. 2975-2977, 1997.

[19] J. Meier, S. Dubail, S. Golay et al., "Microcrystalline silicon and the impact on micromorph tandem solar cells," Solar Energy Materials and Solar Cells, vol. 74, no. 1-4, pp. 457-467, 2002.

[20] M. Yoshimi, T. Sasaki, T. Sawada et al., "High efficiency thin film silicon hybrid solar cell module on $1 \mathrm{~m}$ 2-class large area substrate," in Proceddings of the 3rd World Conference on Photovoltaic Energy Conversion, pp. 1566-1569, May 2003.

[21] P. D. Veneri, P. Aliberti, L. V. Mercaldo, I. Usatii, and C. Privato, "Influence of microcrystalline silicon bottom cell on micromorph tandem solar cell performance," Thin Solid Films, vol. 516, no. 20, pp. 6979-6983, 2008.

[22] I. A. Yunaz, K. Sriprapha, S. Hiza, A. Yamada, and M. Konagai, "Effects of temperature and spectral irradiance on performance of silicon-based thin film multijunction solar cells," Japanese Journal of Applied Physics, vol. 46, no. 4, pp. 1398-1403, 2007.

[23] S. Y. Myong, S. S. Kim, O. Chevaleevski, K. H. Jun, M. Konagai, and K. S. Lim, "Optimization of P-A-SiC:H/P-NC$\mathrm{SiC}: \mathrm{H}$ double layer structure for a high efficiency A-Si:H 
based solar cell," in Proceddings of the 29th IEEE Photovoltaic Specialists Conference, pp. 1226-1229, May 2002.

[24] C.-H. Lin, "Si/Ge/Si double heterojunction solar cells," Thin Solid Films, vol. 518, no. 6, supplement 1, pp. S255-S258, 2010.

[25] T. Nagashima, K. Okumura, K. Murata, Y. Kimura et al., "Three-terminal tandem solar cells with a back-contact type bottom cell," in Proceedings of the 28th IEEE Photovoltaic Specialists Conference, p. 1193, September 2000. 


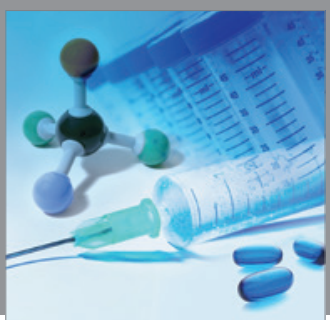

International Journal of

Medicinal Chemistry

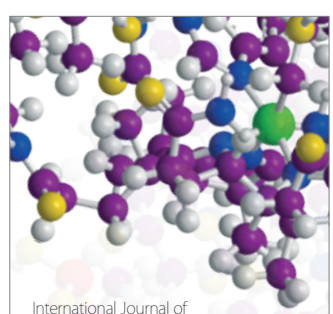

Carbohydrate Chemistry

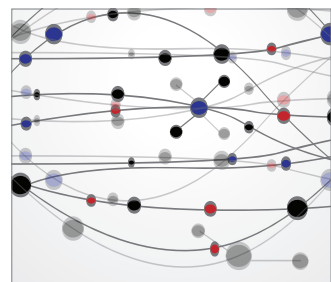

The Scientific World Journal
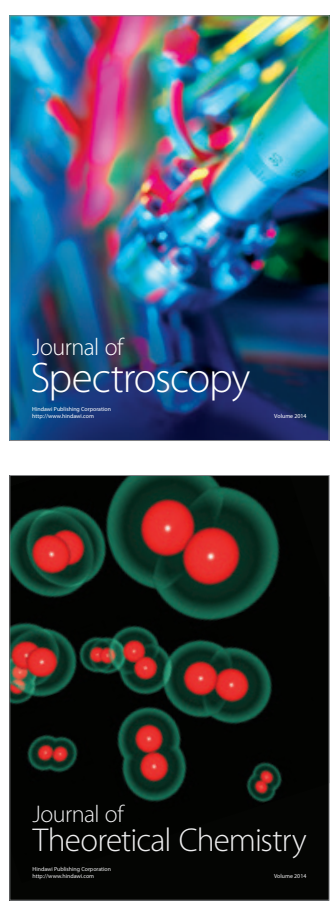
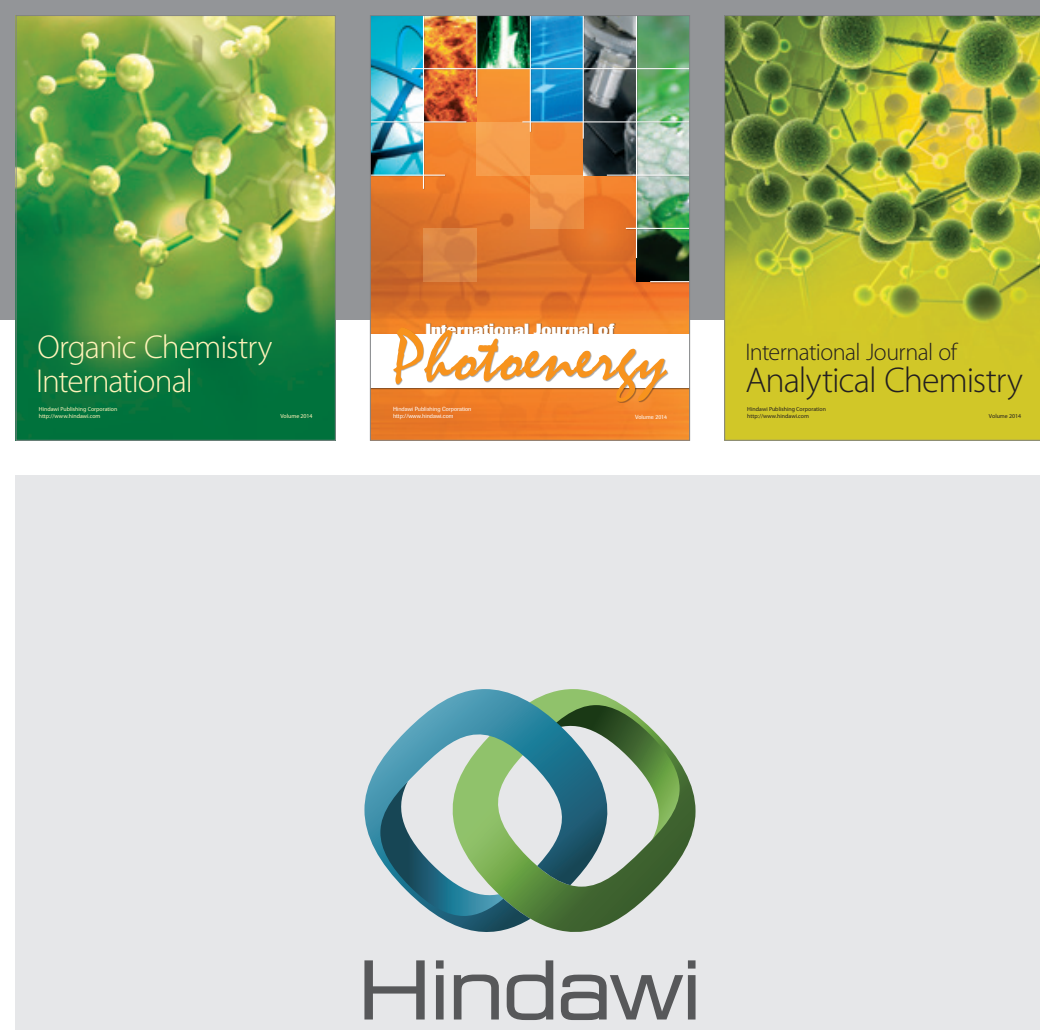

Submit your manuscripts at

http://www.hindawi.com
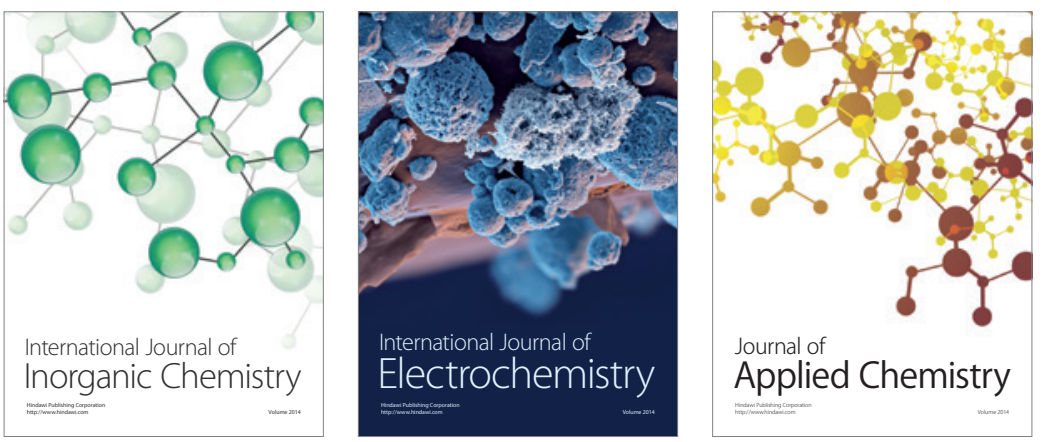

Journal of

Applied Chemistry
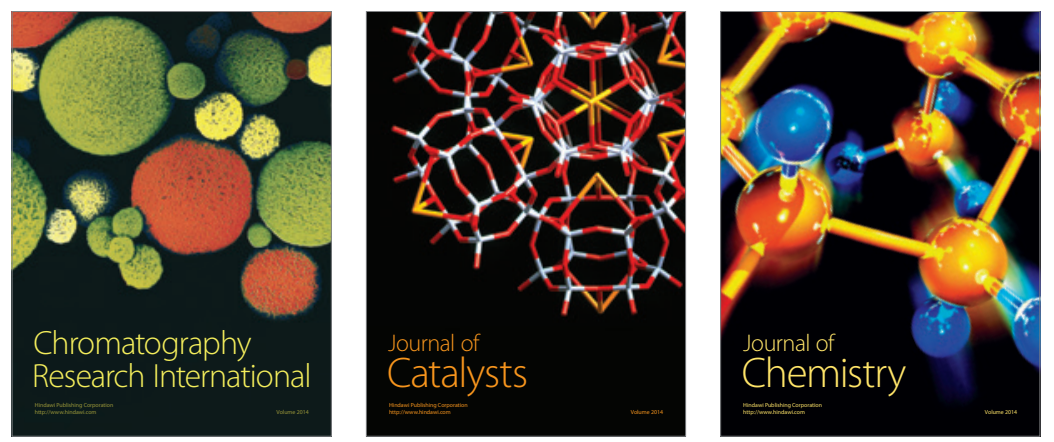
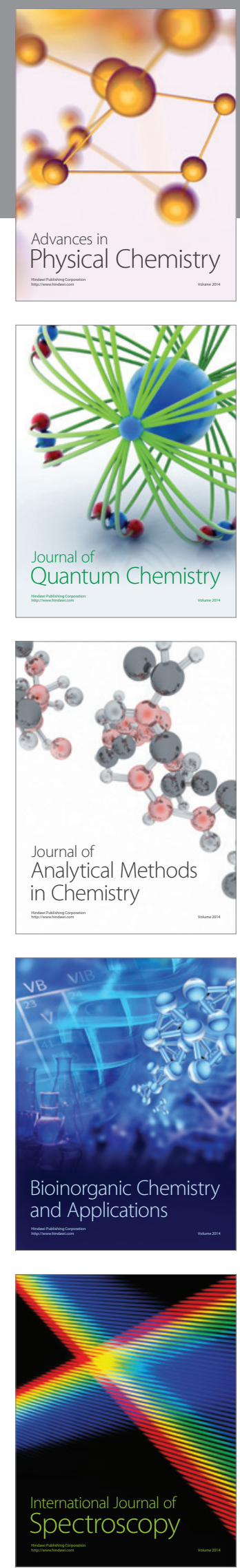